\title{
Sylwia Talar*
}

\section{INTENSYWNOŚĆ KONKURENCJI W ERZE POWSZECHNEGO WYKORZYSTANIA INTERNETU}

\begin{abstract}
Streszczenie. Celem artykułu jest wyszczególnienie sposobów wpływu powszechnego wykorzystania Internetu na intensywność konkurencji oraz wyjaśnienie przyczyn istniejących rozbieżności i sprzecznych poglądów dotyczących oddziaływania globalnej sieci na zmiany konkurencji. Jako narzędzie analityczne wykorzystano koncepcję pięciu sił konkurencji Portera. Dokonano krytycznego przeglądu dotychczasowych badań i uzupełniono go o wnioski wynikające z obserwacji zmian zachodzących we współczesnym środowisku gospodarczym. Na podstawie przeprowadzonej analizy wskazano wielokierunkowe sposoby oddziaływania Internetu na konkurencję w poszczególnych obszarach. Zidentyfikowano także główne przyczyny zróżnicowania opinii występujących w literaturze oraz uzasadniono potrzebę opracowania nowych narzędzi badań konkurencji w warunkach gospodarki internetowej.
\end{abstract}

Słowa kluczowe: Internet, konkurencja, analiza pięciu sił Portera

JEL: O33, L10, L20, D01

\section{WPROWADZENIE}

Dokonujące się zmiany strukturalne związane z upowszechnianiem wykorzystania Internetu i technologii z nim powiązanych prowadzą do transformacji systemu społeczno-gospodarczego i powstania nowego jego modelu. W odniesieniu do niego jest stosowanych wiele różnych określeń, takich jak: gospodarka internetowa, nowa gospodarka, gospodarka cyfrowa, społeczeństwo informacyjne, społeczeństwo sieciowe, gospodarka elektroniczna i inne. Nie ma wątpliwości, iż powszechne wykorzystanie globalnej sieci zasadniczo przekształca warunki działania wszystkich uczestników gry rynkowej, generując przy tym liczne wyzwania i tworząc wiele nowych możliwości. Wywołane rewolucją cyfrową zmiany w zasadach funkcjonowania gospodarki od samego początku przyciągają też uwagę badaczy i analityków .

W stosunkowo powszechnym przekonaniu Internet wpływa na wzrost konkurencji. Opinia ta jest konsekwencją postrzegania globalnej sieci jako narzędzia umożliwiającego łatwy i tani dostęp do wielu zasobów, a zwłaszcza do danych

${ }^{*}$ Uniwersytet Ekonomiczny w Katowicach, Wydział Ekonomii, Katedra Międzynarodowych Stosunków Ekonomicznych. 
i informacji. Przyjmuje się też, że wykorzystanie Internetu prowadzi do zmniejszenia lub likwidacji wielu barier tkwiących w dotychczasowym systemie produkcji i sposobie zaspokajania potrzeb, co z kolei ułatwia podejmowanie działalności gospodarczej, daje zupełnie nowe możliwości jej prowadzenia oraz tworzenia całkiem nowych rodzajów produktów. $Z$ tego punktu widzenia, wykorzystanie Internetu tworzy szczególnie sprzyjające warunki do powstawania nowych firm i ułatwia im nie tylko wejście na rynek, lecz także ekspansję zagraniczną. Małe i średnie firmy mogą dzięki temu działać i rozwijać się w sposób podobny do dużych korporacji.

Opinie na temat skutków wykorzystania globalnej sieci nie są jednak jednoznaczne. Można spotkać też poglądy mówiące, że udostępnieniu za pośrednictwem Internetu małym firmom możliwości zarezerwowanych wcześniej tylko dla dużych korporacji towarzyszą analogiczne zmiany z punktu widzenia dużych firm, które uzyskują dzięki globalnej sieci możliwość integrowania przewag charakterystycznych dla małych firm (takich jak przedsiębiorczość czy elastyczność) ze swoimi dotychczasowymi zasobami (Anthony 2012). W konsekwencji występowanie takich samych warunków dla nowych, małych jak i dużych podmiotów, przy uwzględnieniu bardzo szybkiego tempa zmian, a w szczególności nietrwałości przewag konkurencyjnych w warunkach hiperkonkurencji, ponownie stawia te pierwsze w gorszej sytuacji w stosunku do tych drugich.

Opracowania i analizy uwarunkowań działania współczesnych przedsiębiorstw często koncentrują się wokół zagadnień związanych z intensywnością konkurencji oraz narzędziami bądź metodami stosowanymi w rywalizacji między tymi podmiotami. Dominuje w nich strukturalne podejście prezentowane przez M. Portera, a jego koncepcja pięciu sił konkurencji jest powszechnie wykorzystywanym narzędziem badania intensywności konkurencji. Także sam Porter ocenia wpływ Internetu na konkurencję (Porter 2001b; Porter, Heppelmann 2014), wskazując na ciągłą aktualność tradycyjnych teorii i podstaw przewagi konkurencyjnej w warunkach gospodarki internetowej. Wnioski Portera nie spotkały się jednak z powszechnym uznaniem i pojawiły się głosy krytyczne (Tapscott 2001). Otwarta kwestia oceny skutków powszechnego wykorzystania Internetu dla intensywności konkurencji uzasadnia potrzebę podjęcia badań w tym obszarze.

Celem artykułu jest wyszczególnienie sposobów wpływu powszechnego wykorzystania Internetu na intensywność konkurencji w oparciu o koncepcję pięciu sił konkurencji Portera oraz wyjaśnienie przyczyn istniejących rozbieżności i sprzecznych poglądów na ten temat. Przyjęto, iż Internet w sposób wielokierunkowy oddziałuje na intensywność konkurencji, a źródłem istniejących kontrowersji wokół oceny tego oddziaływania są różnice w rozumieniu istoty Internetu i jego ekonomicznej roli, brak kompleksowego podejścia do analizy tego problemu i niedostosowanie metod badania konkurencji do nowego paradygmatu gospodarki internetowej. Podstawę osiągnięcia wskazanego celu stanowi krytyczny przegląd literatury oraz synteza wyników dotychczasowych badań w powiązaniu 
z wnioskami wynikającymi z obserwacji zmian współczesnego środowiska ekonomicznego i zachowań podmiotów determinowanych ciągłym i szybkim rozwojem technologii internetowych.

\section{ISTOTA INTERNETU I JEGO ZNACZENIE EKONOMICZNE}

Pojęcie Internetu nie jest jednoznacznie definiowane. W ogólnym, stosunkowo powszechnym rozumieniu Internet to światowa sieć komputerowych sieci stosujących wspólny protokół komunikacyjny TCP/IP, który stanowi wspólny język mający zapewnić interoperacyjność sieci posługujących się różnymi lokalnymi protokołami (McKnight, Bailey 2000: 28). Jest to jednak wąskie ujęcie koncentrujące się na samej sieci. W szerszym znaczeniu Internet to nie tylko infrastruktura, komputery, technologia sieciowa, ale także znajdująca się w nim zawartość i uniwersalna platforma do tworzenia licznych usług, kreatywności i innowacyjności (Kahn, Cerf 1999).

Różnice w sposobie rozumienia Internetu mają swoje odzwierciedlenie także na poziomie oceny jego znaczenia jako innowacji technologicznej. Porter traktuje Internet jedynie jako następny etap procesu rozwoju technologicznego czy kolejny wynalazek, mający po prostu ważne znaczenie (Porter 2001b). Według Tapscotta, głównego adwersarza Portera w tym temacie, Internet, w porównaniu do innych technologii umożliwiających powszechną komunikację, stanowi jakościowo coś absolutnie nowego, bezprecedensowego, co jest w stanie wchłonać pozostałe środki komunikacji, takie jak telewizja, radio czy telefon (Tapscott 2001).

O szczególnym charakterze Internetu świadczą jego ogromne możliwości w zakresie szybkiej, efektywnej, zintegrowanej, multimedialnej i interaktywnej wymiany informacji. Ta bardzo wysoka użyteczność Internetu łączy się ze względną łatwością jego użycia oraz relatywnie niskimi kosztami dostępu i korzystania z globalnej sieci. Oprócz funkcji komunikacyjnych Internet pełni również szereg funkcji bardzo istotnych ze stricte ekonomicznego punktu widzenia, takich jak: dystrybucyjne, informacyjne, marketingowe, transakcyjne czy organizacyjno-koordynacyjne. Generalnie niskie koszty dostępu do Internetu w połączeniu z jego funkcjonalnością prowadzą do radykalnego zmniejszenia kosztów transakcyjnych w działalności gospodarczej. Innowacyjność i wyjątkowość Internetu polega nie tyle na zastosowaniu w nim całkiem nowych rozwiązań technicznych, ile na umożliwieniu integracji różnych technologii i rozwiązań. Łączenie technologii i procesów do tej pory całkowicie odrębnych uruchamia reakcję łańcuchową i tworzy szczególnie sprzyjające warunki do rozwoju innowacyjności.

Odmienne rozumienie istoty Internetu i skali jego innowacyjności prowadzi do zróżnicowanych, a czasami wręcz sprzecznych wniosków dotyczących ekonomicznych skutków jego wykorzystania. Biorąc pod uwagę fakt oddziaływania 
Internetu na praktycznie wszystkie aspekty i obszary współczesnego życia społeczno-gospodarczego, zasadnym jest przyjęcie szerokiejdefinicji uwzględniającej wszystkie jego warstwy i funkcje. W takim właśnie znaczeniu stosowny jest ten termin w niniejszym artykule.

\section{CZYNNIKI DETERMINUJĄCE INTENSYWNOŚĆ KONKURENCJI W ŚWIETLE KONCEPCJI PORTERA}

Konkurencja jest jedną z podstawowych kategorii ekonomicznych, jednak w poszczególnych nurtach, teoriach ekonomicznych oraz w zależności od badacza tego problemu jest często różnie rozumiana (Gorynia, Łaźniewska 2009: 13-17). Według Portera (2001a: 23; Magretta 2012: 9) konkurencja to rywalizacja w osiągnięciu jak największych zysków, której zasięg wyznaczają granice danego sektora, a jej intensywność zależy w sumie od pięciu sił kształtowanych przez: firmy obecne na rynku, klientów, dostawców, potencjalnych nowo wchodzących oraz substytuty (rys. 1).

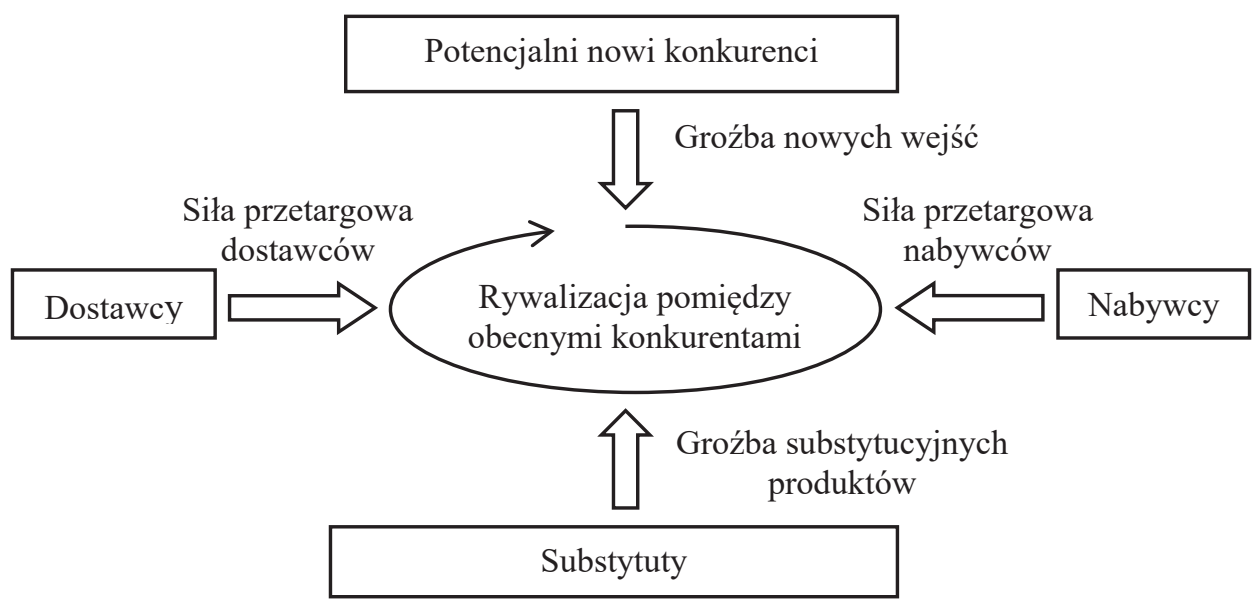

Rysunek 1. Pięć sił konkurencji Portera

Źródło: (Porter 1992: 22).

Porter wskazuje także, jakie konkretnie czynniki wpływają na zagrożenia wywoływane każdą z wymienionych sił (Porter 1992: 21-49). Ponadto siły te mogą wzajemnie się wzmacniać, ale ostatecznie o konkurencji decyduje najsilniejsza z nich. Postęp techniczny, procesy zachodzące w gospodarce światowej i inne przekształcenia w otoczeniu przedsiębiorstw stale zmieniają znaczenie i sposób oddziaływania każdej z tych sił. Obok trendów zmian w natężeniu konkurencji 
zróżnicowanych w zależności od sektora występują megatrendy transformujące całą gospodarkę i społeczeństwo. Internet jest takim czynnikiem, który istotnie wpływa na zmiany we wszystkich obszarach, chociaż skala i tempo tych zmian mogą być różne na poszczególnych rynkach. W kolejnych częściach artykułu przeanalizowano oddziaływanie Internetu na każdą z sił konkurencji.

\section{INTERNET A ZAGROŻENIE ZE STRONY SUBSTYTUTÓW}

Substytuty to najtrudniejszy obszar analizy ze względu na praktycznie nieograniczony zakres czynników mających wpływ na możliwość ich pojawienia się; branż, z których mogą one pochodzić oraz formy, w jakiej mogą występować. Nie tylko postęp techniczny, który sam w sobie jest nieprzewidywalny, ale także zmiana zachowań, stylu życia, kultury, mogące nastąpić z różnych przyczyn, niosą ze sobą wzrost ryzyka pojawienia się substytutu lub zaniku popytu na dany produkt. Z jednej strony Internet wpływa na zwiększenie rozmiaru rynku poprzez wzrost ogólnej efektywności sektora i tym samym zmniejsza presję konkurencyjną, ale $z$ drugiej strony powoduje nasilenie konkurencji wskutek pojawienia się wielu nowych możliwości związanych z jego wykorzystaniem oraz różnymi potencjalnymi zastosowaniami Internetu i technologii z nim powiązanych (Porter 2001b). Stosunkowo silniejsze jest oddziaływanie Internetu na wzrost aniżeli spadek zagrożenia substytutami przede wszystkim ze względu na umożliwienie powstania zupełnie nowych ich form. Na szeroki wachlarz możliwych substytutów determinowanych wykorzystaniem Internetu składają się w szczególności:

- same produkty - np. nowe dobra cyfrowe, stare scyfryzowane, dobra ,amatorskie" (np. muzyka, film, informacje) powstające dzięki nowym możliwościom tworzenia oraz redukcji kosztów ich produkcji i dystrybucji (Gillerot, Minton 2000: 226);

- sposoby zaspokajania potrzeb - np. indywidualne zaspokajanie własnych potrzeb z wykorzystaniem sieci, które oznacza zaangażowanie konsumentów w proces produkcji (np. nauczyciel sam tworzy dla siebie podręcznik na podstawie różnych źródeł dostępnych w Internecie);

- kanały dostępu do produktów - np. powszechny dostęp do produktów, których nabycie za pośrednictwem tradycyjnych form było nieopłacalne lub niemożliwe (dotyczy zwłaszcza produktów regionalnych, lokalnych, rzemieślniczych); wydatne ułatwienie bezpośredniego dostępu do bardzo dużej ilości produktów i dostawców (np. substytutem tradycyjnych usług pośrednictwa stają się porównywarki cenowe bądź platformy handlowe, takie jak Allegro);

- modele prowadzenia działalności - np. udostępnianie produktów za darmo bądź po bardzo niskiej cenie, a zarabianie w innych obszarach działalności (np. na usługach marketingowych) lub oferowanie korzystania z produktu 
(np. używanego) zamiast sprzedaży nowego, gdzie substytutem towaru staje się usługa (w tym tzw. współkonsumpcja).

Jak wynika z powyższego zestawienia, substytutem może być już nie tylko sam produkt bądź usługa, ale także sposób zaspokajania potrzeb konsumentów czy model biznesowy. W tych warunkach nieadekwatnym staje się tradycyjne rozumienie substytutu jako innego produktu mogącego spełniać taką samą funkcję jak wyroby danego sektora (Porter 1992: 40). Powszechne wykorzystanie Internetu zmienia jednak nie tylko znaczenie pojęcia substytutu. Powinno także skłonić do rozważenia zasadności stosowania sektorowego podejścia w badaniach ekonomicznych.

\section{INTERNET A GROŹBA NOWYCH WEJŚĆ}

Ryzyko pojawienia się nowych konkurentów wiązane jest bezpośrednio z istnieniem barier wejścia na dany rynek, w tym też reakcją działających już na nim firm. Poza barierami wynikającymi ze specyfiki sektora występują także ogólne, naturalne bariery prowadzenia działalności gospodarczej, do których zalicza się przestrzeń i czas. Internet pozwala przede wszystkim zredukować te uniwersalne bariery, powodując spadek znaczenia lokalizacji i umożliwiając zwiększenie zasięgu geograficznego działania niemal każdej firmy oraz przyśpieszenie tempa ich ekspansji. W efekcie pojawiają się na rynku nowi gracze z krajów, które dotychczas w konkurencji nie uczestniczyły lub robiły to w bardzo ograniczonym zakresie. W ciągu jednego dnia lub nocy powstają nowe firmy, które od samego początku mają wymiar międzynarodowy a nawet globalny. Chodzi nie tylko o firmy typu born global, ale także tzw. micromultinationals (Dimitratos, Johnson, Slow, Young 2003: 164-174; Talar, Kos-Łabędowicz 2014: 571-582). To wszystko zwiększa ryzyko pojawienia się nowych konkurentów, ale także niepewność co do kierunku, z którego mogą się oni wyłonić - czy będzie to kraj rozwinięty, czy rozwijający się; zupełnie nowa firma, czy już istniejąca, ale pochodząca z innego kraju; czy będzie to duża, mała, czy mikro firma.

Ryzyko i niepewność dotyczy nie tylko kierunku geograficznego, wieku i wielkości nowego konkurenta, ale także sektora, z którego może pochodzić. Dobrze znanym przykładem pojawienia się nowych konkurentów spoza sektora jest wejście przez firmy handlu detalicznego czy przedsiębiorstwa telekomunikacyjne $z$ ofertą usług finansowych, a nawet bankowych, które tradycyjnie świadczone były przez profesjonalnych usługodawców ${ }^{1}$. Przypadki te potwierdzają wpływ Internetu na zmiany granic wyznaczających obszar walki konkurencyjnej, a wręcz

${ }^{1}$ Znamiennym może być przykład już z połowy lat 90., kiedy firma Microsoft podjęła działania mające na celu przejęcie firmy Intuit produkującej oprogramowanie w obszarze finansów osobistych, które ostatecznie jednak nie zostało sfinalizowane ze względu na obawy banków, że Microsoft może 
ich zacieranie się. Stanowi to dodatkowy argument za poszukiwaniem odmiennego od sektorowego podejścia do analizy intensywności konkurencji. Problem definicji granic między sektorami wskazywany jest już w niektórych opracowaniach (Surblytè 2015; Hirt, Willmott 2014).

Oddziaływanie Internetu na obniżenie barier wejścia w szczególności polega na istotnym ułatwieniu i zmniejszeniu kosztów dostępu do potrzebnych zasobów, takich jak: różnego rodzaju informacje, wiedza, kapitał ludzki i finansowy. Internet pełni również funkcję narzędzia ułatwiającego dotarcie do szerokiego grona potencjalnych klientów i pozwalającego zwiększyć efektywność działania w wielu obszarach, a tym samym zmniejszyć zapotrzebowanie na niektóre zasoby (np. praca, kapitał). Ponadto, jeśli uwzględnimy wpływ Internetu na wzrost outsourcingu, to w sposób pośredni będzie on wpływać też na obniżenie barier wejścia, umożliwiając ,produkcję” dóbr bez potrzeby posiadania własnych zdolności produkcyjnych (majątku trwałego). Sam Internet stanowi także ważny czynnik do wykorzystania bezpośrednio w działalności gospodarczej, gdyż nie tylko zastępuje tradycyjne kanały dystrybucji, ale przede wszystkim umożliwia funkcjonowanie przedsiębiorstw tylko w wirtualnej przestrzeni bez konieczności inwestowania w środki trwałe. Tym samym, Internet wprowadza całkiem nowe rozwiązania biznesowe, ale też pozwala łatwo je kopiować lub wykorzystywać jako inspirację dla tworzenia nowych rozwiązań, stanowiących modyfikację poprzednich lub będących wynikiem integracji różnych już istniejących. Przy tym, Internet jako czynnik produkcji jest dostępny dla wszystkich na niemal takich samych zasadach.

Powyższą ocenę należy uzupełnić o wnioski wynikające z bardziej wnikliwej obserwacji współczesnego środowiska gospodarczego. Przede wszystkim nie można sprowadzać analizowanego problemu tylko do konkurencji w Internecie (pomiędzy firmami internetowymi) lub konkurencji między firmami internetowymi a tradycyjnymi. Zagadnienie to ma bowiem znacznie szerszy wymiar i dotyczy relacji między wszystkimi podmiotami tworzącymi wspólnie jedną gospodarkę, którą obecnie można nazwać gospodarką internetową (OECD 2012: 25). Jest to taka gospodarka, w której Internet jest powszechnie wykorzystywany przez wszystkich, ale może być wykorzystywany do bardzo różnych celów i w wysoce zróżnicowany sposób. W konsekwencji sam dostęp do Internetu nie daje przewagi konkurencyjnej². Podstawowym czynnikiem wpływającym na możliwość konkurowania jest umiejętność odpowiedniego co do skali i formy wykorzystania Internetu. Umiejętność tę należy współcześnie zaliczyć do głównych źródeł barier wejścia. Okazuje się, że jeśli uznamy Internet za coś więcej niż tylko uniwersalny kanał dystrybucji i środek komunikacji oraz uwzględnimy

stać się także bankiem i możliwą reakcję Departamentu Bezpieczeństwa USA. Por. (Tapscott 2014: 20) oraz informacje prasowe dotyczące firmy Intuit.

${ }^{2}$ Pominięcie tego faktu prowadzi do wniosku, który prezentowany jest także przez Portera. Mówi on, iż upowszechnienie Internetu oznacza zanik przewagi na nim opartej (Porter 2001b: 18). 
jego szybki rozwój, to umiejętne jego wykorzystanie wymagać będzie odpowiednich kompetencji i dodatkowych zasobów, a także gotowości do ciągłych zmian. Ponadto Internet może nie tyle eliminować potrzebę prowadzenia fizycznej działalności, ale nawet ją wzmacniać, a zatem per saldo zwiększać zapotrzebowanie na zasoby. Potwierdzają to przedsięwzięcia w obszarze IT podejmowane przez duże tradycyjne korporacje, których ekspansja, według prognoz Accenture, ma zdominować kolejne lata (Accenture 2014). Możliwość wykorzystania większej liczby czynników z różnymi wariantami ich kombinacji wymaga przede wszystkim wysokich kompetencji i umiejętności, czyli zasobów niematerialnych, które generalnie są trudno dostępne. McKinsey na podstawie swoich badań wskazuje, iż nie wszystkie procesy i funkcje podlegają automatyzacji czy informatyzacji i w konsekwencji firmy stają wobec konieczności znalezienia odpowiednich pracowników (tzw. talentów) (Hirt, Willmott 2014). Nie chodzi przy tym tylko o informatykó $w^{3}$, ale także specjalistów z zakresu strategii oraz kreatywnego modelowania działalności biznesowej z wykorzystaniem Internetu i technologii cyfrowych. Bardzo ograniczony dostęp do wysokiej klasy specjalistów z dziedziny wykorzystania ICT staje się najważniejszą barierą wejścia na rynek w warunkach powszechnego wykorzystania Internetu ${ }^{4}$. Ponadto, jeśli weźmie się pod uwagę dynamiczną, globalną naturę Internetu, konieczność właściwego identyfikowania kluczowych informacji w nieprzebranych jego zasobach oraz ciągłego wyszukiwania nowych zastosowań dla rosnących możliwości Internetu, to kluczowym czynnikiem decydującym o przewadze konkurencyjnej może stać się czas. W związku z powyższym umiejętności efektywnego wykorzystania czynnika czasu będą stanowić jedną z najważniejszych kompetencji przyszłości. Konsekwencją powszechnego wykorzystania Internetu jest wiec nie tyle obniżenie barier wejścia, co zmiana ich źródeł - nie są to już zasoby materialne, ale przede wszystkim wysokie kompetencje i umiejętności.

Dodatkową kwestią wymagającą uwzględnienia przy analizie konkurencji $\mathrm{w}$ warunkach gospodarki internetowej są efekty sieciowe, które oznaczają wzrost wartości produktów wraz ze wzrostem liczby osób z nich korzystających. Po przekroczeniu punktu krytycznego następuje eksplozja wartości sieci, która wraz z każdym jej nowym użytkownikiem może rosnąć nawet w postępie geometrycznym ${ }^{5}$. Uzyskanie efektów sieci wymaga zatem odpowiednio dużej skali działania i sprzyja, a nawet wymusza stosowanie pewnych standardów, co z kolei rodzi ryzyko dyskryminacji (zwłaszcza mniejszych firm) i wystąpienia antykonkurencyjnych

\footnotetext{
${ }^{3}$ Polskie Towarzystwo Informatyczne wymienia ponad dwadzieścia specjalizacji informatycznych, które podlegają certyfikacji na Europejski Ceryfikat Zawodu Informatyka (EUCIP) (PTI 2015).

${ }^{4} \mathrm{Na}$ przykład badanie przeprowadzone przez firmę konsultingową NewVantage Partners w 2012 roku wśród amerykańskich firm z listy Fortune 1000 wykazało, iż zatrudnienie lub wynajęcie specjalisty z dziedziny Big Data jest niezwykle trudne i brak jest odpowiedniego źródła „nowych talentów" w tym obszarze (NewVantage Partners 2012).

${ }^{5}$ Por.: prawo wyceny sieci według Metcalfe`a, Reeda, Beckströma (Ciesielski 2013: 40-45).
} 
efektów (Urrutia 2000: 5). Efekty sieciowe mogą więc prowadzić do poważnego naruszania zasad konkurencji i sprzyjać monopolizacji. Sytuacja taka implikuje wzrost barier wejścia i sprzyja dominacji jednej, ewentualnie kilku dużych firm, zgodnie z zasadą ,pierwszy bierze wszystko".

\section{INTERNET A SIŁA PRZETARGOWA DOSTAWCÓW I NABYWCÓW}

Z uwagi na podobne czynniki determinujące siłę przetargową dostawców i nabywców, te dwie siły ujęto łącznie. Dodatkowo uwzględniono wpływ Internetu na zmianę roli pośredników. Zgodnie z koncepcją Portera na siłę przetargową dostawców i nabywców wpływa przede wszystkim koszt ich zmiany.

Z punktu widzenia nabywców, Internet ułatwia dostęp do bezpośrednich informacji dotyczących produktów, ich substytutów oraz samych dostawców. Zwiększa to transparentność ofert, różnorodność produktów i świadomość oraz wiedzę nabywców, a w konsekwencji ich niezależność, wymagania i siłę przetargową w relacji do dostawców. Czynnikiem dodatkowo ułatwiającym zmianę dostawców jest pewna standaryzacja technologii związana z funkcjonowaniem oraz wykorzystaniem sieci. Ponadto Internet ułatwia zawieranie transakcji bezpośrednio między ostatecznym nabywcą a producentem, eliminując tym samym potrzebę udziału $\mathrm{w}$ tym procesie tradycyjnych pośredników. Całkowity zanik pośredników oznaczałby rozproszenie nabywców, co z kolei miałoby negatywny wpływ na ich siłę przetargową wobec dostawców. Jednak obok eliminowania pośredników można obserwować silny trend tworzenia ich nowych rodzajów, takich jak infopośrednicy (np. porównywarki cenowe) pełniący funkcję szybkiego dostępu do potrzebnych informacji czy platformy transakcyjne (np. Allegro) zwiększające bezpieczeństwo zawieranych transakcji (Gillerot, Minon 2000: 230-231). Działania tego typu pośredników ponownie zwiększają siłę przetargową nabywców wobec dostawców.

Powyższe oddziaływanie Internetu na zmniejszenie kosztów zmiany dostawców i wzrost siły przetargowej nabywców równocześnie powoduje negatywny wpływ na siłę przetargową dostawców. Dodatkowo wirtualizacja funkcji marketingowo-sprzedażowych u dostawców i w konsekwencji brak bezpośredniego kontaktu z nabywcami utrudnia im zdobyć lojalność klientów. Internet może być jednak wykorzystywany także jako narzędzie do budowania trwałych relacji z nabywcami. Dzieje się to poprzez tworzenie internetowych społeczności skupionych wokół danego tematu lub poprzez dopasowywanie oferty do indywidualnych potrzeb klientów na podstawie informacji o ich zachowaniach zakupowych zebranych z Internetu. Wówczas, pomimo bardzo szerokiej oferty i technicznej łatwości zmiany dostawców (np. kilka kliknięć lub przesunięć palcem), nabywcy stają się emocjonalnie związani z dostawcami i koszty ich zmiany zaczynają wzrastać.

Analiza możliwych sposobów oddziaływania Internetu na siłę przetargową nabywców i dostawców prowadzi do wniosku o równoważeniu się tych sił 
W sytuacji kiedy dany podmiot jest równocześnie nabywcą i dostawcą. W rzeczywistości specyfika konkretnego przypadku będzie decydowała o ostatecznym efekcie. Zasadniczą jednak kwestią w tym kontekście jest określenie charakteru relacji między nabywcą a dostawcą w łańcuchu dostaw i zmian, jakie w tym obszarze zachodzą pod wpływem wykorzystania Internetu.

W modelu Portera zarówno nabywcy jak i dostawcy są traktowani jako konkurenci. $\mathrm{Z}$ tego wynika, iż podmioty te dążą do osiągnięcia celu wzajemnie się wykluczającego, a zatem wzrost zysku jednego osiągany jest kosztem zmniejszenia zysku lub poniesienia straty przez drugiego (gra o sumie zerowej). Całkowicie pominięty jest tutaj jednak fakt, iż w jednym procesie tworzenia wartości może brać udział szereg firm i, pomimo że są to podmioty samodzielne oraz wykonują odrębne działania, to są ze sobą powiązane, gdyż w efekcie końcowym o zyskach każdej z nich będzie decydować powodzenie gotowego produktu na rynku, czyli wspólnie wytworzona wartość. Żadna z tych firm nie byłaby w stanie samodzielnie wytworzyć takiej wartości, a zatem w interesie ich wszystkich, jak też w interesie końcowych nabywców, powinno leżeć uzyskanie w najbardziej efektywny sposób jak największej wartości, co pozwoliłoby zwiększyć korzyści wszystkim uczestnikom łańcucha (gra o sumie dodatniej).

Coraz większą uwagę zwraca się na kooperacyjne relacje podmiotów w łańcuchu dostaw ${ }^{6}$. W tym przypadku nie ma konkurencji między dostawcami a nabywcami i dążenie do optymalizacji występuje na poziomie całego łańcucha, a nie danej firmy. To przenosi także konkurencję z poziomu pojedynczych firm na poziom łańcuchów dostaw lub nawet sieci, czego przykładem jest działalność firmy Li\&Fung (Fung V. K., Fung W. K., Wind 2008). W konsekwencji na konkurencję nie wpływa siła przetargowa, stopień wzajemnego uzależnienia i wysokość kosztów zmiany pomiędzy uczestnikami tego łańcucha, ale przede wszystkim ich umiejętności kooperacyjne i koordynacyjne (Cao, Zhang 2013). Te kluczowe kompetencje decydują o sukcesie na rynku zdominowanym przez sieciowe formy organizacji przedsiębiorstw ${ }^{7}$. W tych warunkach, zamiast przewag konkurencyjnych w ujęciu proponowanym przez Portera, należałoby rozważać przewagi kooperacyjne. Internet w tym względzie niesie ze sobą wyjątkowe ułatwienia i to nie tylko od strony czysto technicznej (komunikacji, dostępności informacji w czasie rzeczywistym o realizowanych działaniach, zarządzania z jednego miejsca całym łańcuchem), ale też od strony społecznej, rozwijając tzw. kulturę sieciową sprzyjającą współpracy. Zastąpienie relacji konkurencyjnych relacjami kooperacyjnymi skutkuje spadkiem intensywności konkurencji.

${ }^{6}$ Dogłębną analizę różnych zagadnień związanych z problematyką współpracy w łańcuchu dostaw, z uwzględnieniem ICT przeprowadza Cao i Zhang (2013).

${ }^{7}$ Problematyka usieciowienia przedsiębiorstw i sieci biznesowych jest szeroko podejmowana w literaturze polskiej, w szczególności w naukach o zarządzaniu (por. np. Koźmiński, Latusek-Jurczak, 2014; Czakon, 2015 i inne pozycje tego autora) oraz z perspektywy wpływu ich na konkurencyjność przedsiębiorstw (np.: Ratajczak-Mrozek, 2010; Mitręga, 2010; Rosińska-Bukowska, 2015). 
Według Tapscotta i Williamsa (2008: 28-59), Internet prowadzi nawet do całkowitej zmiany dotychczasowego modelu tworzenia wartości i powstania tzw. produkcji partnerskiej. Wskazują oni, iż model ten polega na masowym podejmowaniu przez ludzi wspólnych działań w ramach samoorganizujących się struktur i opiera się na otwartości, partnerstwie (współpracy ze wszystkimi), dzieleniu się zasobami oraz działaniu na skalę globalną. Produkcja partnerska ma stanowić alternatywę dla tradycyjnych korporacji i ostatecznie je zastąpić. Chociaż takie oceny wydają się obecnie przesadzone, to jednak potwierdzają wyjątkowość Internetu pod względem jego oddziaływania na konkurencję i potrzebę szukania nowych sposobów jej badania.

\section{INTERNET A RYWALIZACJA MIĘDZY ISTNIEJĄCYMI KONKURENTAMI}

Siła konkurencji między działającymi już na danym rynku przedsiębiorstwami zależy od wielu różnych czynników, wśród których do najważniejszych Porter zalicza liczbę konkurentów i ich siłę, strukturę kosztów oraz rodzaj realizowanej strategii konkurencji.

Internet jako otwarta sieć światowa umożliwia rozszerzenie zasięgu geograficznego rynku i dodatkowo nasila globalizację (Yip 2000), co oznacza konieczność uwzględnienia w walce konkurencyjnej większej liczby konkurentów (głównie zagranicznych i w tym globalnych), większej ilości aspektów, a także powoduje mniejszą przewidywalność realizowanych strategii konkurencji przez tak wielu różnych rywali. Wszystko to wpływa na wzrost intensywności konkurencji ${ }^{8}$.

W stosunkowo powszechnej opinii, wykorzystanie Internetu tworzy również presję na stosowanie strategii konkurencji cenowej i w ten sposób dodatkowo zwiększa intensywność konkurencji. Jest to związane z możliwościami szybkiej obniżki kosztów dzięki wykorzystaniu Internetu. To z kolei sprzyja koncentracji firm na efektywnościowych aspektach działalności, ale też utrudnia zachowanie w tajemnicy tych działań. Ponadto ułatwiony dzięki Internetowi i coraz powszechniejszy outsourcing umożliwia zaopatrywanie się u tych samych dostawców w te same komponenty i w efekcie prowadzi do rosnącej standaryzacji i homogeniczności produktów, a zatem dodatkowo ułatwia kopiowanie produktów i skutkuje upodabnianiem się firm do siebie. Patrząc tylko z tej perspektywy, trudno jest budować przewagę konkurencyjną w oparciu o zróżnicowanie (Porter 2001b: 9). Istotny wpływ Internetu na poprawę efektywności powoduje także

\footnotetext{
${ }^{8}$ Wniosek ten potwierdza analiza wpływu samego procesu internacjonalizacji i globalizacji na natężenie konkurencji, przeprowadzona także przy wykorzystaniu modelu pięciu sił Portera przez Gorynię i Jankowską (2004).
} 
obniżenie udziału kosztów zmiennych w stosunku do stałych w ogólnej strukturze kosztów przedsiębiorstwa. Cena zależy zatem przede wszystkim od wielkości sprzedaży, a to powoduje nacisk na dużą skalę zbytu, dodatkowo zaostrzając konkurencję.

Opisane wyżej oddziaływanie Internetu na rywalizację pomiędzy obecnymi konkurentami powinno prowadzić do wzrostu intensywności konkurencji przejawiającego się rozproszeniem struktury rynku. Tymczasem badania (Wang, Zhang 2015; Gillerot, Minon 2000: 233-237) wskazują na rosnącą koncentrację, nawet w odniesieniu do takich sektorów jak e-commerce. Widoczna jest też ekspansja fuzji i przejęć oraz różnego rodzaju strategicznych porozumień między firmami. Konsolidacja może być efektem samej nasilającej się konkurencji, kiedy firmy popadające w problemy są przejmowane przez swoich dotychczasowych konkurentów lub inne firmy chcące rozszerzyć działalność (Foster, McChesney, Jonna 2011: 1-23). Ponadto wzrost znaczenia cyfrowych przewag skłania duże korporacje do przejmowania małych firm i start-upów charakteryzujących się kulturą sprzyjającą wykorzystaniu i rozwojowi kompetencji cyfrowych. Jeśli przyjmiemy, że działalność w środowisku powszechnego wykorzystania Internetu wymaga bardzo wysokich kompetencji i umiejętności oraz dużej skali (efekty sieci), to te nowe uwarunkowania będą sprzyjać zdominowaniu rynku przez niewielką liczbę dużych graczy działających na poziomie globalnym. Obserwowane strategie konkurencji stosowane przez podmioty również nie potwierdzają powszechnych opinii mówiących o dominacji konkurencji cenowej wskazując na silny trend różnicowania się przedsiębiorstw ${ }^{9}$. Normą staje się budowanie i utrzymywanie relacji z nabywcami w oparciu o świadczenie im usług aniżeli sprzedaż produktów (Oxford Economics, PTC 2014: 3). Natomiast rozwój powiązań międzyorganizacyjnych utrudnia naśladowanie działań konkurentów, gdyż wymagałoby to przekopiowywania całych systemów, a nie konkretnych rozwiązań.

\section{PODSUMOWANIE}

Przeprowadzona analiza badań i opracowań oraz wnioski z obserwowanych zmian zachodzących w działalności podmiotów wskazują, iż powszechne przekonanie o rosnącej na skutek wykorzystania Internetu intensywności konkurencji wynika z bardzo pobieżnej oceny rzeczywistości gospodarczej oraz zawężonego, technicznego rozumienia istoty Internetu i skali jego innowacyjności.

${ }^{9}$ Przykłady wpływu Internetu na możliwości różnicowania i to zarówno dla firm internetowych jak i tradycyjnych, argumenty za tym przemawiające oraz wyniki badań przeprowadzonych na hiszpańskich firmach przemysłowych potwierdzające zależność między wykorzystaniem Internetu i realizacją strategii zróżnicowania prezentowane są przez Fernandeza i Nieto (2006: 182-195). 
Uwzględnienie szerszego spektrum oddziaływania Internetu i jego dynamicznej natury pozwoliło wskazać liczne sposoby jego wpływu na spadek intensywności konkurencji. Internet jako czynnik kształtujący warunki współczesnej konkurencji ma zatem charakter ambiwalentny. Przykładem jest możliwe jego oddziaływanie zarówno na obniżanie barier wejścia na rynek jak i ich wzrost, presję na konkurencję cenową jak i nowe możliwości różnicowania.

Rozbieżności w ocenach skutków wykorzystania Internetu dla konkurencji w poszczególnych opracowaniach mają kilka przyczyn. W pierwszej kolejności należy wskazać na pewne nieścisłości w określeniu zakresu walki konkurencyjnej w warunkach powszechnego wykorzystania Internetu. Konkurencja sprowadzana jest często do rywalizacji na tzw. rynku internetowym, który jest traktowany jako odrębny rynek lub między firmami tradycyjnymi a tzw. internetowymi (działającymi wyłącznie w wirtualnej przestrzeni). Tymczasem tradycyjne przedsiębiorstwa również wykorzystują Internet, a sposób i zakres tego wykorzystania zależy od przyjętej strategii. Jedną z podstawowych kwestii jest zatem ustalenie, czy gospodarka internetowa stanowi odrębną część gospodarki i np. handel internetowy jest także odrębnym, równoległym rynkiem w stosunku do handlu tradycyjnego, na którym w tym samym czasie mogą być sprzedawane te same towary, czy też jest to jedna gospodarka i jeden rynek. Przyjęcie pierwszej opcji nie odpowiada obecnej rzeczywistości, w której Internet jest technologią powszechnego wykorzystania.

Innym źródłem trudności jednoznacznej oceny wpływu Internetu na intensywność konkurencji są następujące ciągle zmiany. Ewolucji podlega nie tylko sam Internet (np. Web 2.0, Web 3.0), ale także zachowania konsumentów, strategie przedsiębiorstw, które swoimi zachowaniami również doprowadzają do zmian warunków rynkowych dla, innych podmiotów. Dynamika całego systemu gospodarczego i jego uwarunkowań powoduje, że pewne zachowania bądź zależności występujące $\mathrm{w}$ danym momencie mogą z czasem zaniknąć, zmienić swoją siłę lub ulec całkowitemu odwróceniu.

$\mathrm{Na}$ ocenę intensywności konkurencji w warunkach gospodarki internetowej mają wpływ także zastosowane metody jej analizy. Przyjęcie tradycyjnego, sektorowego podejścia wymaga precyzyjnego określenia granic rynku (sektora), na którym badana jest konkurencja oraz jasnego wskazania, kto z kim konkuruje, jakimi produktami i na jakim obszarze geograficznym. Biorąc pod uwagę, iż Internet prowadzi do zaniku granic pomiędzy sektorami, analizowanie konkurencji z tej perspektywy oraz traktowanie wszystkich jako konkurentów może prowadzić do mylnych wniosków. Instrumenty analizy stosowane w tradycyjnej gospodarce nie są w tym przypadku adekwatne do analizy gospodarki internetowej, gdyż radykalna zmiana modelu jej funkcjonowania wymaga zastosowania nowych kategorii do jej opisu i narzędzi do eksploracji. Pominięcie tego faktu wydaje się być podstawowym błędem z dyskusji toczącej się nad wpływem Internetu na konkurencję. 


\section{BIBLIOGRAFIA}

Accenture (2014), Accenture Technology Vision 2014: Every Business Is a Digital Business. From Digitally Disrupted to Digital Disrupters.

Anthony S. D. (2012), The New Corporate Garage, „Harvard Business Review”, September.

Cao M., Zhang Q. (2013), Supply Chain Collaboration. Roles of Interorganizational Systems, Trust, and Collaborative Culture, Springer, London.

Ciesielski M. (red.) (2013), Sieci w gospodarce, PWE, Warszawa.

Czakon W. (2015), Sieci międzyorganizacyjne w naukach o zarządzaniu - w kierunku sieciowych modeli biznesu, „Studia Ekonomiczne”, „Zeszyty Naukowe Uniwersytetu Ekonomicznego w Katowicach", nr 217.

Dimitratos P., Johnson J., Slow J., Young S. (2003), Micromultinationals: New types of firms for the global competitive landscape, "European Management Journal", vol. 21, issue 2.

Fernandez Z., Nieto M. J. (2006), The internet: competitive strategy and boundaries of the firm, „International Journal of Technology Management”, vol. 35, no. 1-4.

Foster J. B., McChesney R. W., Jonna R. J. (2011), Monopoly and Competition in Twenty-First Century Capitalism, „Monthly Review”, vol. 63, no. 2.

Fung V. K., Fung W. K., Wind Y. (2008), Konkurowanie w płaskim świecie, WAiP i Wyższa Szkoła Przedsiębiorczości i Zarządzania im. Leona Koźmińskiego, Warszawa.

Gillerot D., Minton M. (2000), Development of the Internet, Market Structure, and Commercial Practices: The Case of the Publishing Sector, „Communications and Strategies”, no. 38.

Gorynia M., Jankowska B. (2004), Konkurencja w branży a internacjonalizacja i globalizacja, „Gospodarka Narodowa”, nr 11-12.

Gorynia M., Łaźniewska E. (red.) (2009), Kompendium wiedzy o konkurencyjności, PWN, Warszawa.

Hirt M., Willmott P. (2014), Strategic principles for competing in the digital age, "McKinsey Quarterly", May.

Kahn R. E., Cerf V. G. (1999), What Is The Internet (And What Makes It Work), http://www.cnri. reston.va.us/what is internet.html\#A\%20DEFINITION\%20FOR\%20THE\%20INTERNET [dostęp: 10.06.2015].

Koźmiński A.K., Latusek-Jurczak D. (red.) (2014), Relacje międzyorganizacyjne w naukach o zarzązaniu, Wolters Kluwer, Warszawa.

Magretta J. (2012), Understanding Michael Porter. The Essential Guide to Competition and Strategy, HBRP, Boston.

McKnight L. W., Bailey J. P. (ed.) (2000), Internet Economics, MIT.

Mitręga M. (2010), Zdolność sieciowa jako czynnik przewagi konkurencyjnej na rynku przedsiębiorstw, Wydawnictwo Uniwersytetu Ekonomicznego w Katowicach.

NewVantage Partners (2012), Big Data Executive Survey. Themes \& Trends, http://newvantage. com/wp-content/uploads/2015/01/NewVantage_Big_Data_Themes_Trends_final.pdf [dostęp: 30.06.2015].

OECD (2012), OECD Internet Economy Outlook 2012, OECD Publishing, Paris.

Oxford Economics, PTC (2014), Smart, connected products: Manufacturing's next transformation, http://www.ptc.com/File\%20Library/Topics/Smart\%20Connected\%20Products/Oxford-Economics_Smart-Connected-Products-Report.pdf [dostęp: 30.06.2015].

Porter M. (1992), Strategia konkurencji. Metody analizy sektorów i konkurentów, PWE, Warszawa. Porter M. (2001a), Porter o konkurencji, PWE, Warszawa.

Porter M. (2001b), Strategy and the Internet, "Harvard Business Review", March. 
Porter M., Heppelmann J.E. (2014), How Smart, Connected Products Are Transforming Competition, "Harvard Business Review", November.

PTI (2015), Lista specjalizacji informatycznych (zawodów), http://www.eucip.pl/?what=31 [dostęp: 30.06.2015].

Ratajczak-Mrozek M. (2010), Sieci biznesowe a przewaga konkurencyjna przedsiębiorstw zaawansowanych technologii na rynkach zagranicznych, Wydawnictwo Uniwersytetu Ekonomicznego w Poznaniu, Poznań.

Rosińska-Bukowska M. (2015), Koncepcja oceny konkurencyjności przedsiębiorstw sieciowych, [w:] J. Toruński, M. Chrząścik (red.), Wiedza i doświadczenie a współczesne koncepcje i narzędzia zarzadzania organizacja, Uniwersytet Przyrodniczo-Humanistyczny w Kielcach, Siedlce.

Surblytè G. (ed.) (2015), Competition on the Internet, "MPI Studies on Intellectual Property and Competition Law", vol. 23.

Talar S., Kos-Łabędowicz J. (2014), Internacjonalizacja w warunkach gospodarki internetowej na przykładzie firm micromultinationals, „International Business and Global Economy”, nr 33.

Tapscott D. (2001), Rethinking Strategy in a Networked World (or Why Michael Porter is Wrong about the Internet), "Strategy+Business", issue 24, http://www.strategy-business.com/article/19911?pg=0 (dostęp: 12.06.2015 r.)

Tapscott D. (2014), The Digital Economy Anniversary Edition: Rethinking Promise and Peril in the Age of Networked Intelligence, McGraw-Hill.

Tapscott D., Williams A. D. (2008), Wikinomia. O globalnej wspótpracy, która zmienia wszystko, Wydawnictwa Akademickie i Profesjonalne, Warszawa.

Urrutia B. (2000), Internet and its effects on competition, Paper delivered to the Universidad Internacional Menendez Pelayo (UIMP) Workshop, Barcelona, 10 July.

Wang F., Zhang X-P.(S.) (2015), The role of the Internet in changing industry competition, "Information \& Management", vol. 52, issue 1, January.

Yip G. (2000), Global Strategy In the Internet Era, "Business Strategy Review”, vol. 11, issue 4.

\title{
THE INTENSITY OF COMPETITION IN THE ERA OF UBIQUITOUS INTERNET USAGE
}

\begin{abstract}
The aim of this paper is to specify how ubiquitous use of the Internet can influence the intensity of competition and explain the reasons for different opinions that exist in this respect. The study is carried out on the basis of the Porter's five forces analysis. The critical review of existing research on this issue has been done and conclusions from the observation of changes in the contemporary economic environment added. Possible ways in which the Internet has an impact on not only the rise, but mainly fall in intensity of competition have been pointed out. The key causes of ambiguous views suggested in the literature have been identified and the need of finding new tools for competition research in the Internet economy conditions explained.
\end{abstract}

Keywords: Internet, competition, Porter`s five forces analysis 